\title{
The largest Baltic population of sea trout (Salmo trutta L.): its decline, restoration attempts, and current status
}

\author{
Piotr Dębowski
}

Received - 16 April 2018/Accepted - 05 June 2018. Published online: 30 June 2018; @Inland Fisheries Institute in Olsztyn, Poland Citation: Dębowski P. 2018 - The largest Baltic population of sea trout (Salmo trutta L.): its decline, restoration attempts, and current status Fish. Aquat. Life 26:81-100

\begin{abstract}
The sea trout, Salmo trutta L. population in the Vistula River was the largest in the Baltic Sea. Its primary spawning grounds were located in the Carpathian tributaries in the upper river basin. The fish ascended to spawn in two runs: in winter when the fish were immature and spent nearly a whole year in the river, and in summer when mature fish ascended the river and spawned within a few months. This work presents the fisheries and stocking history and scientific studies of this population from the late nineteenth century. The consequences of the most important changes in the sea trout habitat are tracked from construction in the upper river basin in the 1940s and the damming of the river in its middle reaches in Włocławek in 1969. Despite intense stocking that has been conducted for over one hundred years, catches have declined from over 100 tons to nearly zero in recent years. The current state of the population and the possibilities of restoring it are discussed in light of genetic studies.
\end{abstract}

Keywords: management; migration; restitution; sea trout; stocking; Vistula River

\section{Introduction}

Migratory sea trout is an anadromous biological form of the brown trout, Salmo trutta L., species. The

P. Dębowski [" $\left.{ }^{\circ}\right]$

Department of Migratory Fishes in Rutki, Inland Fisheries Institute in Olsztyn, Poland

e-mail: p.debowski@infish.com.pl distinguishing feature of this form is its migrations between fresh and marine waters. Adult fish ascend rivers to spawn, and the young fish produced from spawning remain in the rivers for a period of one to several years. Once they have reached the smolt stage they migrate to the sea, where they remain until they mature sexually and then undertake spawning migrations to rivers. The period they spend in the sea ranges from six months to, most frequently, two to three years (Jonsson 1985, Klemetsen 2003, Cucherousset et al. 2005).

The natural range of occurrence of the brown trout includes Europe and Iceland, the large islands of the Mediterranean Sea, the Atlas Mountains in north Africa, Anatolia and Lebanon, and the Aral Sea drainage basin. The migratory form of the species does not occur throughout this range and is not found south of $42^{\circ} \mathrm{N}$ on the Atlantic coast or in the Mediterranean Sea drainage basin (Elliott 1989). It is common in the Baltic Sea drainage basin, where there are an estimated 650 populations, primarily in the southern part of the sea (ICES 2018).

The occurrence of sea trout in northern Europe is the result of recolonization following the glacial periods, which most likely happened via the seas by the migratory form (Elliott 1994). Thus, the existence of resident populations indicates where the initial migratory range of migratory sea trout was. In Poland,

(c) Copyright by Stanisław Sakowicz Inland Fisheries Institute in Olsztyn.

(C) 2018 Author(s). This is an open access article licensed under the Creative Commons Attribution-NonCommercial-NoDerivs License (http://creativecommons.org/licenses/by-nc-nd/3.0/). 
this is primarily the highlands and ranges of mountains in the south and the lake district in the north (Sych 1998). There are, however, many indications that in the distant past sea trout also spawned in many rivers in central Poland, and some researchers even propose that sea trout occurred in nearly every part of what is today Poland (Cios 2003). Changes in hydrology resulting from logging and the development of agriculture, primarily in lowlands, followed later by industrialization significantly reduced sea trout range. Further reductions in their range caused by construction on rivers and damming, mainly for energy production, have been conducted since the early twentieth century.

In order to inventory sea trout rivers in the Baltic Sea drainage basin, it was assumed that in Poland there are currently 25 rivers in which migratory sea trout spawn (HELCOM 2011). The concept of a sea trout population is not

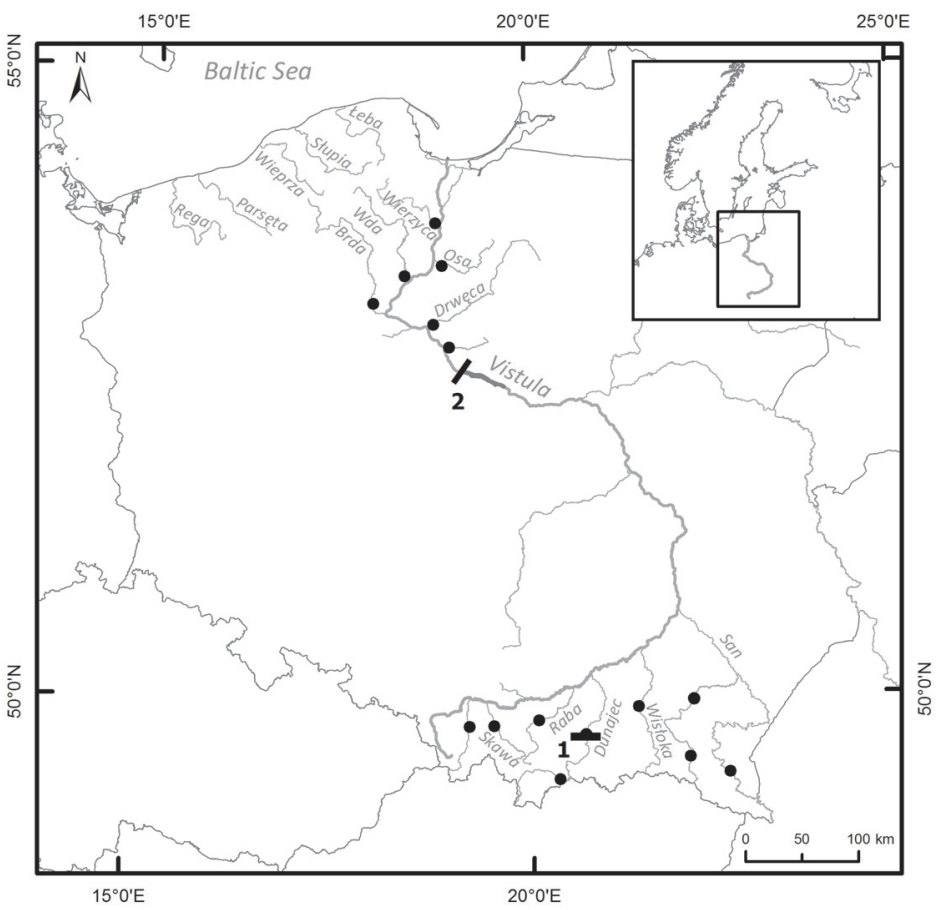

Figure 1. Map of the Vistula River system. Points denote main barrages. 1 Rożnów Dam, 2- Włocławek Dam. easily defined. Traditionally, a population was considered to comprise a group of fish originating from a given river basin that was isolated from other populations by its specific spawning site and had, consequently, specific characters that resulted from the different environment it inhabited (Guyomard 1999). Often, such populations were divided using these same criteria into even smaller ones linked with specific tributaries or river segments (Ferguson 1989, 2006). The more detailed this division becomes, however, the less reproductive isolation there is, and, thus, the subpopulations are less differentiated. It appears that under the conditions in Poland it would be sensible to divide populations, or stocks, as they are often referred to, of sea trout into those that are associated with the specific tributaries of the Vistula or Oder rivers and coastal rivers. This principle was adopted in the list of Polish sea trout rivers mentioned earlier. Assessing the state of specific populations and designating which are self-sustaining render wide-ranging stocking difficult.

The largest and most important sea trout river in Poland was the Vistula (Fig. 1; Bartel 2002, HELCOM

2011). It is the longest Baltic river $(1,020 \mathrm{~km})$ and is second only to the Neva River in the size of its basin $\left(194,000 \mathrm{~km}^{2}\right)$ and average streamflow $\left(1,046 \mathrm{~m}^{3} / \mathrm{s}\right)$. Accordingly, as was stated previously, Vistula sea trout was a mix of stocks linked with specific tributaries. Atlantic salmon, Salmo salar L. also ascended the Vistula River. Historically, these two species were not differentiated from one another, which makes it difficult to interpret historical information (Lubecki and Dixon 1925). The first proposal of differentiating sea trout from salmon is in Dixon's papers from 1924 (Dixon 1924a, 1924b, 1924c), which was followed a year later by a publication by Schechtel (1925), who discusses the specific differences between these two species and presents an analysis of historical sources and contemporary information on them. It is observed in these works that the salmon were far less numerous in the Vistula than were sea trout (Schechtel 1925) and that they only ascended the Skawa and Soła rivers to spawn and were absent, for example, from the Dunajec River (Dixon 1924b, Schechtel 1925, Kulmatycki 1932, Kołder 1946), which was the 
primary sea trout spawning tributary in the upper Vistula River basin (Kulmatycki 1932).

\section{Seasonal forms}

Sea trout ascended the Vistula River throughout the year. The main run was in winter, after which it decreased significantly, but a certain number of fish ascended throughout spring and summer and this intensified again in the fall (Seligo citing Dixon 1924c, Lubecki and Dixon 1925, Schechtel 1925). According to Schechtel (1925), all of the fish were immature, and they spawned the subsequent year. The first sea trout appeared in the Dunajec River at the end of November, but most of them came in spring. Most of the fish reached the spawning grounds in the upper segments of the river at the end of September and in October (Dixon 1924b, Lubecki and Dixon 1925). In the early 1950s, among the sea trout Żarnecki caught in August and September in the lower Vistula River were single specimens with gonads in advanced stages of development, and ovarian mass exceeded as much as 15 to $20 \%$ of fish body weight (Żarnecki 1952a, 1963). The numbers of these fish increased in October. Along with these fish, fully immature specimens were also noted and they constituted all of the catches by November (Żarnecki 1964). Studies conducted in 1952 revealed that the ratio of immature to mature fish was 4:1 (Żarnecki 1964). These groups, which Żarnecki named "winter" and "summer" fish, respectively, and between which there was no intermediate form, barely differed externally (Kukucz 1961, Żarnecki 1963). However, internally, in addition to the degree of sexual maturity, they were significantly different. Above all, the lipid content of the winter fish was more than two-fold higher than that of summer fish, and their abdominal walls were as much as two and one half times thicker (Żarnecki 1952a, Żarnecki and Piątek 1954). The scales of the fish also differed. The edge of the scales of winter fish had sclerite thickening that created a ring, while the scales of summer fish did not. Initially, this was explained by the fact that winter fish, in contrast to summer fish, did not feed prior to ascending the river (Żarnecki 1952a). However, after examining digestive tract content of newly ascending fish, this assumption was proved to be precisely the opposite, and the scale edge growths of the winter fish were attributed to the fact that the intensely feeding fish stored fats but did not grow (Żarnecki and Piątek 1954). Interestingly, the fecundity of these two groups did not differ (Morawska 1967).

Analogous forms were also confirmed in the Vistula salmon population (Żarnecki 1952a, 1956, 1963, 1964, Żarnecki and Piątek 1954). However, since they were significantly lower in number than sea trout, and they disappeared altogether shortly thereafter, the question of the occurrence of this seasonal form was not subjected to more in-depth analysis.

Żarnecki (1952a, 1963) explained the occurrence of two forms, or races, of sea trout as resulting from the two sea trout spawning regions in the Vistula River basin-the Carpathian in the upper areas of the basin, and the Pomeranian in the tributaries of the lower Vistula River. Winter fish, which included the majority of the population, ascended the Vistula River to the main spawning grounds in the Dunajec, Sola, Skawa, Raba, Wisłoka, and San rivers (Kołder 1958) during the migration to which the fish lost 75-85\% of their fat (Kukucz 1960, Jokiel 1961). Summer fish, however, which ascended the river too late and in an advanced maturity state with too little stored fat to reach the Carpathian spawning grounds, spawned in the lower parts of the river basin, mainly in the Drwęca, Brda, Wda, and Wierzyca rivers. Thus, the emergence of these two sea trout forms was an expression of the populations adapting to the geography of the river basin by exploiting its potential possibilities. Therefore, we are dealing with two more or less isolated generative forms (Żarnecki 1963). While Żarnecki's hypothesis does exclude summer fish from spawning at the "upper" spawning grounds, it does not exclude winter fish from spawning in the "lower" river basin, which is something of key importance to the discussion later on. One of the weak points was the analysis of scales collected in 
1951 from adult fish was that it found no differences among them during the freshwater stage of life. No differences were detected with regard to growth rates or smoltification age, which would have been expected if the fish had spent this period in such different environments as Carpathian and Pomeranian rivers (Żarnecki 1957, 1960a). Much later Borzęcka (1999) analysed a much larger collection of scales from the 1953-1968 period and found that summer fish smoltified significantly earlier, but they had been in the sea longer and had matured later. In the 1962-1968 period, the growth of the two forms either did not differ or the winter fish were significantly smaller, despite that fact that during their first year in the sea they had grown faster (Borzęcka 2001). Jokiel (1953a) reports similar observations: in 1952 the largest fish (25\% heavier than those caught at another time) ascended the Vistula River from July to August, which means they were summer fish.

In his considerations, Żarnecki (1952b) relied on the classic work by Berg (1934), who observed two forms similarly to those confirmed in the Vistula in numerous Pacific salmon (Oncorhynchus sp.) populations, in Atlantic salmon in some northern rivers in Russia and Scotland, and in sea trout from the Caspian Kura River. Berg named them by analogy to the winter and spring forms of grain forms. While it is true that the grain analogy was later criticized, Berg's observations were consistent with the situation observed in the Vistula in reference to both sea trout and salmon. Żarnecki (1963) presents two possible explanations for this difference. According to one, there are two separate, hereditarily fixed forms that differ in spawning grounds, migration times, location of gonad maturation (in the sea or in rivers), and amounts of stored reserves. According to the second, a portion of the fish migrate in the Baltic Sea further to the north and inhabit colder waters, which leads to slower gonad development, and different hormonal stimulation that is the impetus to begin spawning migrations. In support of the first hypothesis is the fact that winter sea trout smolts released into the Dunajec returned to the spawning grounds as winter fish (Skrochowska 1969). Żarnecki cites an American experiment by Rich and Holmes conducted in the 1920s using winter and summer Chinook salmon, Oncorhynchus tshawytsha (Walbaum) that indicated that even when progeny is transferred to a new location it retains parental traits (Żarnecki 1963). More recent studies also indicate there is an inherited element linked with migration times in Atlantic salmon, e.g., in southern Norway (Hansen and Jonsson 1991) and in Scotland (Stewart et al. 2002). Genetic studies (RAPD markers) of Caspian sea trout that are a classic example of two distinct forms did not confirm genetic differences between the two (Jamshidi and Kalbassi 2011). Dahl et al. (2004) investigated the timing of sea trout and salmon ascending to the Swedish Dalälven River, but their results revealed that this was not correlated with ovulation, and females of both species that ascended late could ovulate nearly instantly, while those that ascended earlier could delay spawning. The Dalälven River is also associated with an experiment to relocate sea trout that is important for our considerations here. In the 1960s, sea trout eggs from the Dunajec (i.e., the winter form) were exported to Sweden. The fish that were reared in ponds there for two or three generations were released into the Dalälven River, where they were able to maintain their separateness from local sea trout stocks. Dunajec sea trout returned to the river as mature adults, i.e., as summer sea trout, initially before the local fish (in May-June as opposed to September), but after a few years they returned at the same time (Erik Petersson, Swedish University Agricultural Sciences, pers.comm.). Thus, the traits of winter sea trout did not survive the transfer to a new environment, unlike in the experiment cited earlier on Chinook salmon. For the record, we should add that it is unknown what impact holding these fish for several generations in ponds could have had on them. Interestingly, in 1996 eggs from these sea trout, which, as mentioned earlier, originated from Dunajec winter sea trout, were imported to Poland and the fish reared from them were compared to summer sea trout from the Vistula River (Dębowski 2002), and the sea trout from Dalälven smoltified 
slightly earlier and matured earlier than did the Vistula fish.

Generally, fish should remain in the sea for as long as possible. When migration begins earlier, the period of intense feeding in the sea is shortened, growth is worse, and, consequently, reproductive success is reduced (Fleming 1996). Conversely, however, early arrival at spawning grounds can increase reproductive success thanks to better availability of good locations and better fish position during spawning (Vaha et al. 2011). In northern rivers (e.g., Tornio, Tana) the beginning of migration is determined by the melting of ice cover (Lilja and Romakkaniemi 2003, Vaha et al. 2011). According to Larsen et al. (2008), ascending rivers earlier can be a way to avoid the physiological stress associated with lowered water temperatures and increased salinity. In many rivers it has been confirmed that fish that spawn in more distantly located parts of basins begin their spawning migrations significantly earlier than fish that spawn in closer locations (Summers 1996, Gurney et al. 2012). This means that in large drainage basins in which there are many discrete populations with different migration time, there is a migration continuum (Schtickzelle and Quinn 2007, Beacham et al. 2012, Strange 2012, Beacham et al. 2014). However, the phenomenon of seasonal forms is associated with something else, namely immature fish ascending rivers, or premature migration. Quinn et al. (2016) discuss at length this phenomenon, which is observed in different salmonids (Salmonidae) and also in lampreys (Petromyzontidae). They propose two hypotheses to explain this. The first is that if the spawning grounds are very good and access to them is difficult, e.g., because of water temperatures or streamflow fluctuations, it is advantageous to ascend rivers significantly earlier when it is easier even when the cost of doing so is not exploiting marine growth, longer periods of fasting, and greater exposure to predators and diseases. In many instances, however, migration conditions are good enough, and salmon can, as is widely known, migrate very quickly and can cover up to several dozen kilometers daily (Eiler et al. 2015), and reaching even a very remote spawning ground does not require a long time, and even so, they ascend rivers prematurely. In this instance, perhaps the second hypothesis is correct. The sea is a risky habitat, and fish remain there only long enough to attain the reproductive asset of being large. It is very difficult, however, to assess the risk in the sea in temporal units.

As is apparent, we do not have a fully satisfactory, universal explanation of the phenomenon of seasonal forms, but it is clear that this phenomenon certainly does occur, or has occurred, in the Vistula River basin. The Polish literature has accepted Żarnecki's hypotheses that Vistula winter sea trout spawn in the mountains and that summer sea trout spawn in the lower tributaries, and that this diversity is hereditary (Bartel 1988, 1993, 2002, Borzęcka 1998, Wenne et al. 2000, Drywa et al. 2013), even if the experiment in the Dalälven River draws into question this theory of heritability. Jan Jokiel, of the Field Station in Oliwa, Inland Fisheries Institute (IFI), who worked intensely on the subject of sea trout in the lower Vistula River, did not share the hypothesis of the differences of these two forms. According to Jokiel, small numbers of large sea trout that ascended the Vistula River in summer reached the upper tributaries of the Vistula River and once there mixed with fish that had ascended the river in the fall of the previous year, and the period in which the fish ascended the river that extended nearly throughout the year was a function of smolt size, growth rate, and hydrological conditions (Jokiel 1961). Unfortunately, the possibilities of conducting comparative studies of these two sea trout forms ended quickly.

\section{Management}

\section{Up to 1940}

Sea trout and salmon fishing in the upper Vistula and its tributaries was intense in the nineteenth century. In 1891, for example, 1,000 sea trout were caught 
between Nowy Targ and Czorsztyn, which is in the upper reaches of the Dunajec River over $950 \mathrm{~km}$ from the Vistula estuary (Kołder 1958). Stocking sea trout in the upper part of the Vistula River basin began in the nineteenth century. Kołder (1958) collected information on this subject from 1880, which is when the first documented stocking was performed. In the first period up to 1913, nearly four million alevins were released into different rivers, mainly the Dunajec but also the upper Vistula, Skawa, Raba, and San. For the first few years, very small amounts of eggs were imported from Germany, but from 1896 eggs were obtained almost exclusively from the Dunajec River, and from approximately 150,000 to nearly 500,000 alevins were released annually. The Great War interrupted stocking until 1924, when the second period began that lasted until 1940, which is when the dam at Rożnów was completed. During this time, eggs were collected from the Dunajec, mainly upstream from Nowy Targ. A small amount of eggs was also obtained from the Skawa and the Sola. Until 1933, only alevins were released, but later fall fry were also released. During this time, a total of nearly eight million alevins and 22,000 fry were released into the Dunajec, Skawa, Sola, Raba, and Wisłoka.

\section{From 1941 to 1971}

In 1940, the Dunajec was dammed at Rożnów. Even though many fish were observed in the fishway that was constructed two years later, the dam was a serious barrier for sea trout (Juszczyk 1951, Żarnecki and Kołder 1955), which gathered below the dam. Consequently, a substantial number of fish spawned downstream from Rożnów, which was not something that had been observed previously (Kołder 1958). The chances of reaching the spawning grounds of the upper Dunajec River were further worsened by the efforts of water management to catch as many fish as possible for artificial reproduction and stocking. The river downstream from Rożnów was set with fish traps and the fishway was closed, and annual catches in the 1941-1954 period numbered from 209 to
1,381 spawners (Kołder 1946, 1954, 1955, 1957). In the 1952-1958 period a substantial decrease in the number of sea trout in the Dunajec River was noted, while their numbers increased in other tributaries, mainly the Raba and Rudawa, which could have been the result of the stocking (Kołder 1957, Żarnecki 1960b). Rapidly deteriorating environmental conditions in the upper Vistula basin caused by blocked stream continuity and increasing pollution led to the cessation of commercial fishing in 1958 (Kołder 1961). Increasingly, there were difficulties in obtaining spawners in the tributaries of the upper Vistula River. According to unpublished materials from the Kraków Branch of the Polish Anglers Association (PAA), in 1965 two tons of sea trout were caught and in 1966 one ton was caught, but by 1968 only $114 \mathrm{~kg}$ was caught, which led to the discontinuation of this fishery in 1956 in the Sola, in 1967 in the Raba, and in 1968 in the Dunajec (Eysak and Bieniarz 1975). The situation in the lower Vistula River basin in the 1950s was no better. Nearly all the larger tributaries had barriers not far from their mouths and few available spawning grounds were located in lower parts of their tributaries and in a few small streams flowing directly into the Vistula River (Chrzanowski 1971, HELCOM 2011). Only the Drwęca River presented greater potential (Dębowski et al. 1999, Dębowski and Radtke 2000, Wiśniewolski et al. 2004).

Commercial catches in the lower Vistula decreased following World War II. In the 1946-1947 period they exceeded 110 tons annually, but in subsequent periods they decreased as follows: 1948-1949 - 50-60 tons, 1950-1952 - 22-24 tons (Jokiel 1953b), 1953-1960 - approximately 55 tons, 1961-1968 - approximately 25 tons (Bartel 1993). Most of the catches were made in the estuarine segment, which was evidence that a significant part of the stocks were caught (Poczopko and Słonowski 1958). Two distinct peaks in these catches were noted - from October to December (winter sea trout) and from June to August (summer sea trout). In 1952, the former accounted for 61 and the latter for $12 \%$ of the catch (Jokiel 1953b), while in the 
1953-1968 period, after summing the entire period, this figure was 54 and 34\%, respectively (Borzęcka 1998). Until 1957, winter fish dominated decidedly, but later the relationship between these two peaks (which reflected that between the seasonal forms) shifted measurably (Borzęcka 1998), and catches of winter sea trout were more variable than those of summer sea trout (Borzęcka 1999). These fluctuations were caused largely by variable fishing conditions in winter (Poczopko and Słonowski 1958), but the trends were clear: the size of the population was decreasing as was the share of winter fish that had dominated in the early 1950s. The causes certainly included progressing deterioration in spawning conditions in the upper areas of the basin, catches of spawners in the spawning grounds, and intense fishing in the lower Vistula.

Reactions to the deteriorating situation and the even grimmer perspectives associated with renewed interest in the pre-war lower Vistula River cascade project were attempts to catch summer sea trout spawners for stocking purposes in the lower Vistula. The first, and somewhat successful, attempt was in the region of Tczew as early as 1952 and was followed in subsequent years by attempts in the regions of Bydgoszcz and Nieszawa (Jokiel 1953a, Schoennet and Gęsicki 1958, Kossakowski 1959). The beginning of dam construction in Włocławek, the first of ten barriers planned on the Vistula (Szupryczyński 1986), forced a fundamental rethinking of future strategies for the sea trout fishery in the basin. The assumption was that it would have to rely largely on stocking (Chrzanowski 1969, 1971). Each of the seasonal sea trout forms would be treated separately, and summer sea trout spawners caught in the river would be gathered in spawning bases where gametes would be obtained, while winter sea trout spawners would be transferred to hatcheries where they would be held until they reached sexual maturity in the subsequent year (Chrzanowski 1969, Kossakowski 1969). Because of the dam in Włocławek and barriers on most of the tributaries in the lower Vistula River, it was imperative to protect the few existing and still available spawning grounds in the lower Vistula basin (Chrzanowski 1971). During this period, stocking based on catching spawners in the Dunajec River downstream from Rożnów intensified, and, after 1952, it also did in the Rudawa and Raba. Over the span of 13 years, more than 28 million alevins and over a million fry were released (Kołder 1958).

Unpublished materials obtained from the Kraków Branch of the PAA provided information on stocking in tributaries in the upper Vistula River between 1959 and 1971 (Fig. 2). According to these data, more than 2 million alevins were released in

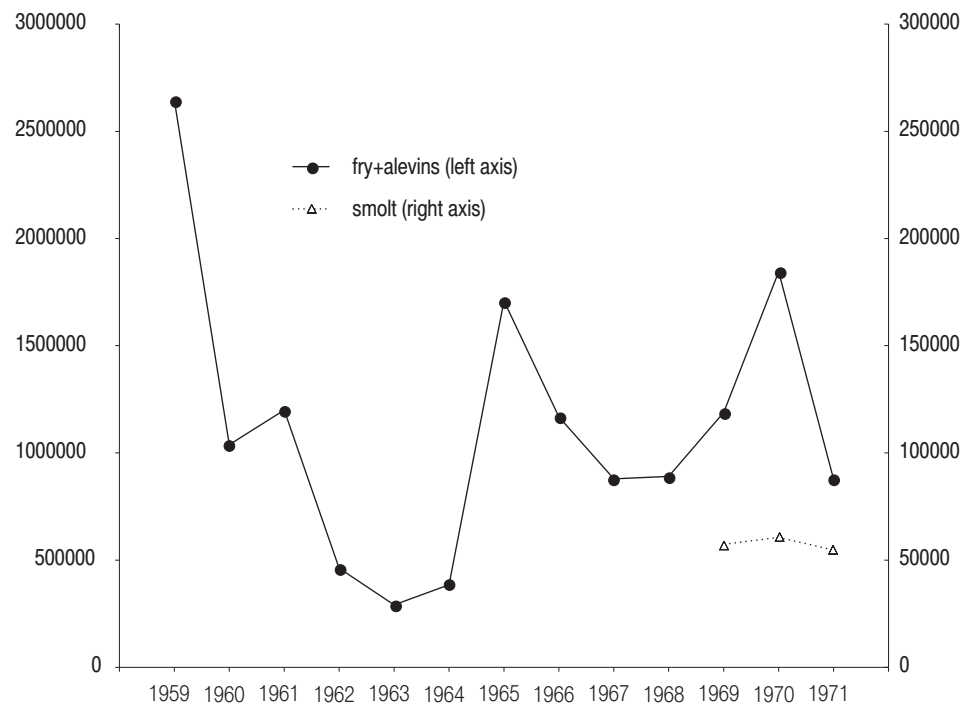

Figure 2. Stocking of the $S$. trutta in the upper part of the system in 1959-1971. 
1959, but in subsequent years this amount decreased substantially, and in some years no stocking with alevins was conducted. About 300,000 fall fry were released annually until 1964 . Over a million fall fry were released in 1965, and in subsequent years the amount of material stocked fluctuated between 460,000 and 880,000. For the first time sea trout smolts $(57,000$ individuals) were released into the Dunajec in 1969. It is noteworthy that this signalled a fundamental shift in stocking policy. Unfortunately, we are not certain as to the origin of these fish. Initially, the eggs were certainly obtained from fish from the Dunajec, but, as we know from the paper cited earlier by Łysak and Bieniarz (1975), because of poor results, these catches were discontinued in 1968. Thus, stocking in 1970 of nearly two million alevins and fry must have been based on eggs brought from the north of Poland. Could these have been eggs from Vistula sea trout? We do not know, but subsequent years indicated that they could have been eggs from Pomeranian rivers. Unfortunately, there is a lack of data on the topic of stocking in the lower Vistula River during this period, although presumably the system developed in the 1950s to catch sea trout spawners and obtain eggs from them facilitated these stocking releases.

\section{From 1972 to 2003}

The construction of the dam across the Vistula River in Włocławek, $266 \mathrm{~km}$ from its estuary and $754 \mathrm{~km}$ from its source, which created a reservoir of approximately $70 \mathrm{~km}^{2}$, was completed in 1969 . One year later, a pool fishway was put into operation with a flow rate of $0.935 \mathrm{~m}^{3} \mathrm{~s}^{-1}$ and located in the pillar between the weir and the hydroelectric plant (Biegała 1972). Studies on the functioning of the pass in 1972-1974 indicated that 19 fish species passed through it, but only an average of half of them were able to negotiate it, and among these fish were only single specimens of sea trout (Bontemps 1977). The functionality of the fishway decreased over time because of erosion that deepened the trough beneath the dam (Szupryczyński 1986), which worsened accessibility of the fishway's entry for fish (Linnik et al. 1998, Woźniewski et al. 1999). Further deterioration led to the construction in 1998 of an auxiliary dam downstream from the main dam (Dębowski 2016, 2017). New studies of the functionality of the fishway conducted in the 1998-2004 period permitted estimating that the number of sea trout navigating the structure was barely 100 individuals annually (Bartel et al. 2007). The mortality of smolts migrating downstream that passed through the turbines of the hydroelectric plant was not observed (Bieniarz and Epler 1977, Bartel and Bontemps 1989). The dam in Włocławek led to the collapse of commercial fisheries in the Vistula that had relied mainly on the migratory fishes of sea trout and vimba bream, Vimba vimba (L.) (Backiel 1985, Wiśniewolski 1987, Bartel et al. 2007), and it changed fundamentally the conditions for maintaining and possibly restoring sea trout to the upper reaches of the drainage basin.

In 1973, the Field Station in Oliwa (IFI) began issuing an annual typescript entitled "Report from the Salmon Management Information Service” compiled by Ryszard Bartel and Zygmunt Zieliński. Issued from 1972-1987, these annual reports presented data concerning the catches, egg collection, and stocking of sea trout and salmon that the authors obtained from questionnaire surveys. From 1987 to 2003, such detailed data was unavailable, but from 2004 similar data have been collected by the Department of Migratory Fish, IFI.

Catches of sea trout in the Vistula River estuary and the lower course of the river in 1972-1991 fluctuated from 31 (in 1983) to 129 tons (in 1990). Of the overall river catches, $80 \%$ were made in the estuarine segment of the river, while from 60 to $91 \%$ were made there in given years (Bartel 1993). This is evidence of the very strong fishing pressure. This was maintained for the subsequent fifteen years or so. Directly downstream from Włocławek an average of approximately 6 tons of sea trout was caught in the 1972-1979 period, while 2.5 tons were caught in the 1980-1987 period. This indicates that during these periods at least approximately 2,000 and 800 sea trout, respectively, reached the dam. 


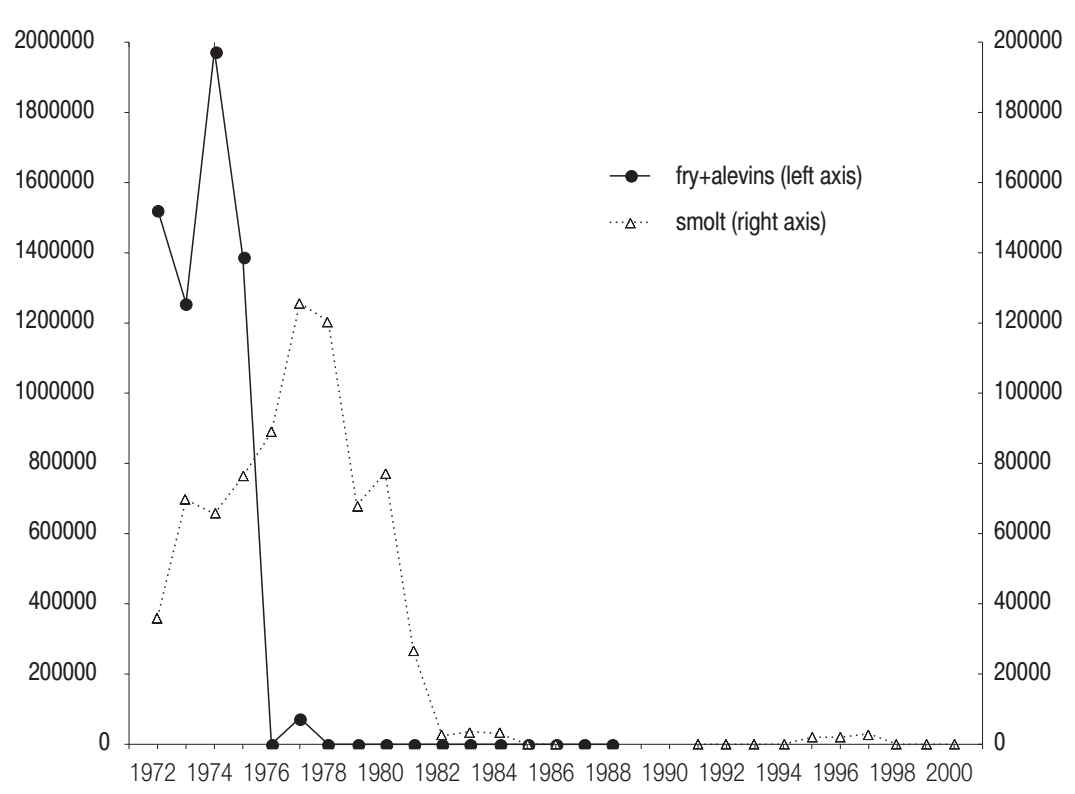

Figure 3. Stocking of the S. trutta in the upper part of the system in 1972-2000.

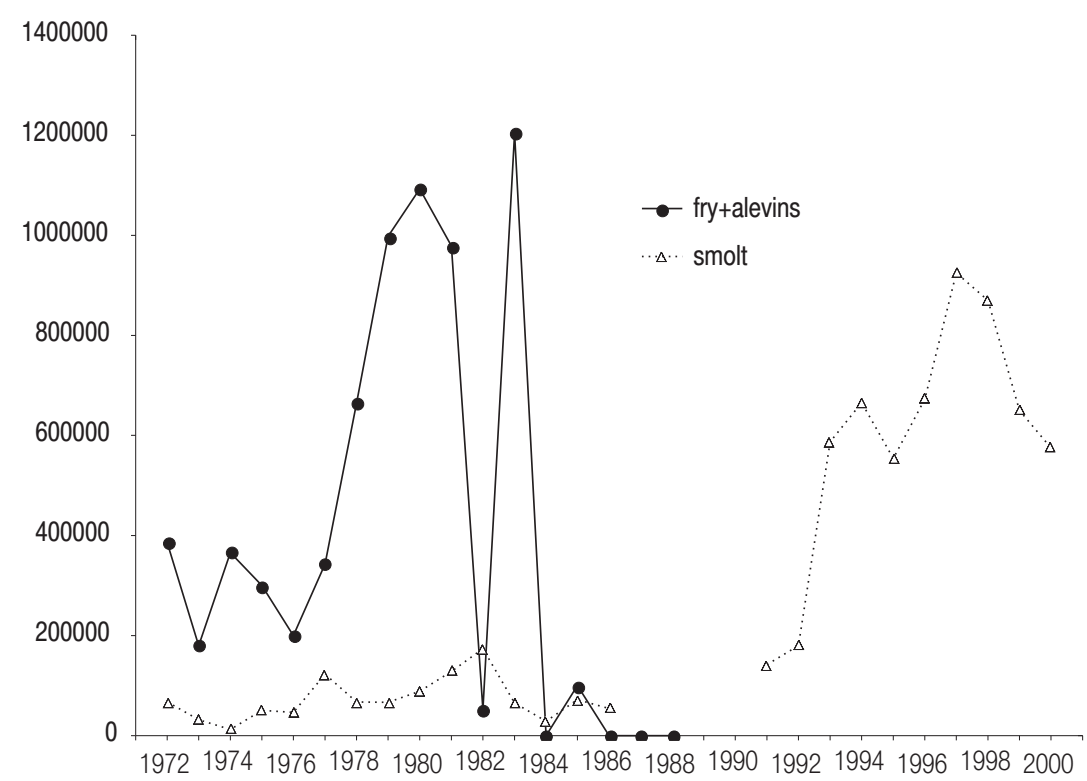

Figure 4. Stocking of the $S$. trutta in the lower part of the system in 1972-2000.

After 1974 an intense stocking of upper Vistula with fry and alevins was almost stopped, partly replaced by smolt releases which were also reduced after 1980 (Fig. 3). Stocking were moved to the lower part of river. Up until 1983, when stocking was discontinued, 6.7 million alevins had been released into the tributaries of the lower Vistula River. Between 1972 and 1987, 1,209,000 smolts were released into the lower Vistula and its tributaries (Fig. 4). Over half of the smolts were released into the Vistula River estuary, 360,000 into the Drwęca, and the remainder into the $200 \mathrm{~km}$ segment of downstream from Włocławek. Approximately 37\% of these were not Vistula sea trout, and they originated from various coastal rivers, mainly the Wieprza (over 200,000), but also the Słupia, Łeba, and Rega and even the 
Parsęta, Łupawa, and Bauda. This procedure, which reached peak numbers in the 1978-1982 period, saw more smolts from other rivers released than Vistula smolts (even as much as $80 \%$ ). This was because of the difficulties in obtaining eggs from Vistula spawners and the availability of eggs from spawners in coastal rivers. This ended in 1985 thanks to moving the location of spawners catches from the region near Włocławek to the Vistula River estuary and the creation of appropriate infrastructure for keeping them (Kossakowski 1969, Bartel 1993). Small quantities of eggs were also obtained in the Drwęca. The entire Vistula River basin was, and is still today, regarded as one population, i.e., recognizing its differences from other drainage basins, and not making the distinction in stocking between fish originating from spawners from the main stream of the Vistula River and from the Drwęca. After 1987, stocking the Vistula River basin with smolts increased substantially, and in some years more than 900,000 individuals were released, while the average from the 1987-2003 period exceeded 550,000 individuals annually (Fig. 4).

There was one more mechanism that mixed populations. In the period of 1961-1987, the tagging of 65,000 (of more than 2.5 million) smolts released into coastal rivers indicated that a large portion of them (from several percent to over half) returning to spawn strayed to the Vistula River (Dębowski and Bartel 1995). As a result, a third group of fish appeared in the river; one that ascended in the fall, later than did the summer fish, that was mature and clearly in breeding colour. In the opinion of Bartel (2002, 2006), these fish originated from the coastal rivers populations. To limit the further propagation of this group, spawners used for stocking purposes were caught only in summer since, presumably, the fish ascending the Vistula River at this time were original Vistula fish (Bartel 2006).

Most of the fish from stocking the Vistula River basin remained in the estuary region, but they were also caught throughout the Baltic Sea from Kattegat to the Gulf of Finland and the Bay of Bothnia, and especially in the region of Gotland
(Bartel et al. 2010). Returning fish that had been released ascended the main stream of the Vistula River and reached the dam in Włocławek (above which only several of the nearly 100,000 tagged smolts released were caught), and this was regardless of whether they had been released in the estuary or in the upper part of the drainage basin. The exception was the fish released into the Drwęca: all of these fish turned into this tributary that is $53 \mathrm{~km}$ downstream from the dam in Włocławek (Dębowski and Bartel 1995).

\section{From 2004}

Catches in the Vistula between 2004 and 2014 were an average of 21 tons, but in subsequent years there was a rapid decline to several hundred kilograms (Fig. 5). This was partially the result of organizational changes in the fisheries and, in the past several years, great pressure from seals, which feed on fish caught in nets in the estuarine segment of the Vistula River (ICES 2018).

Stocking the Vistula River basin with smolts increased to an average number of 763,000 individuals annually (from 2004 to 2017). Of this, an average of 522,000 was released into the lower Vistula River, from several to several tens of thousands into upper tributaries, and the rest to tributaries in the lower

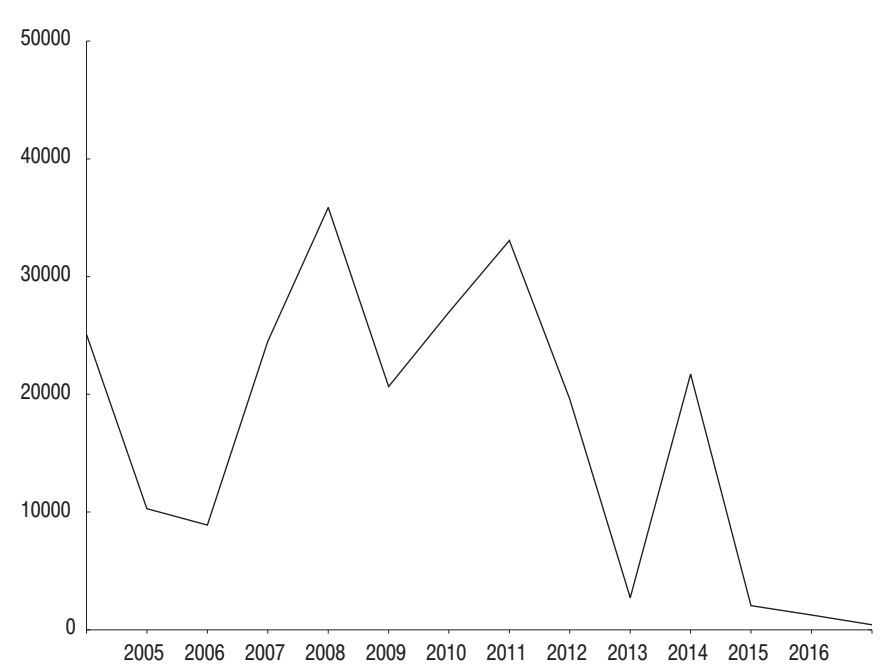

Figure 5. Commercial catches of the S. trutta in 2004-2017 (in kg). 


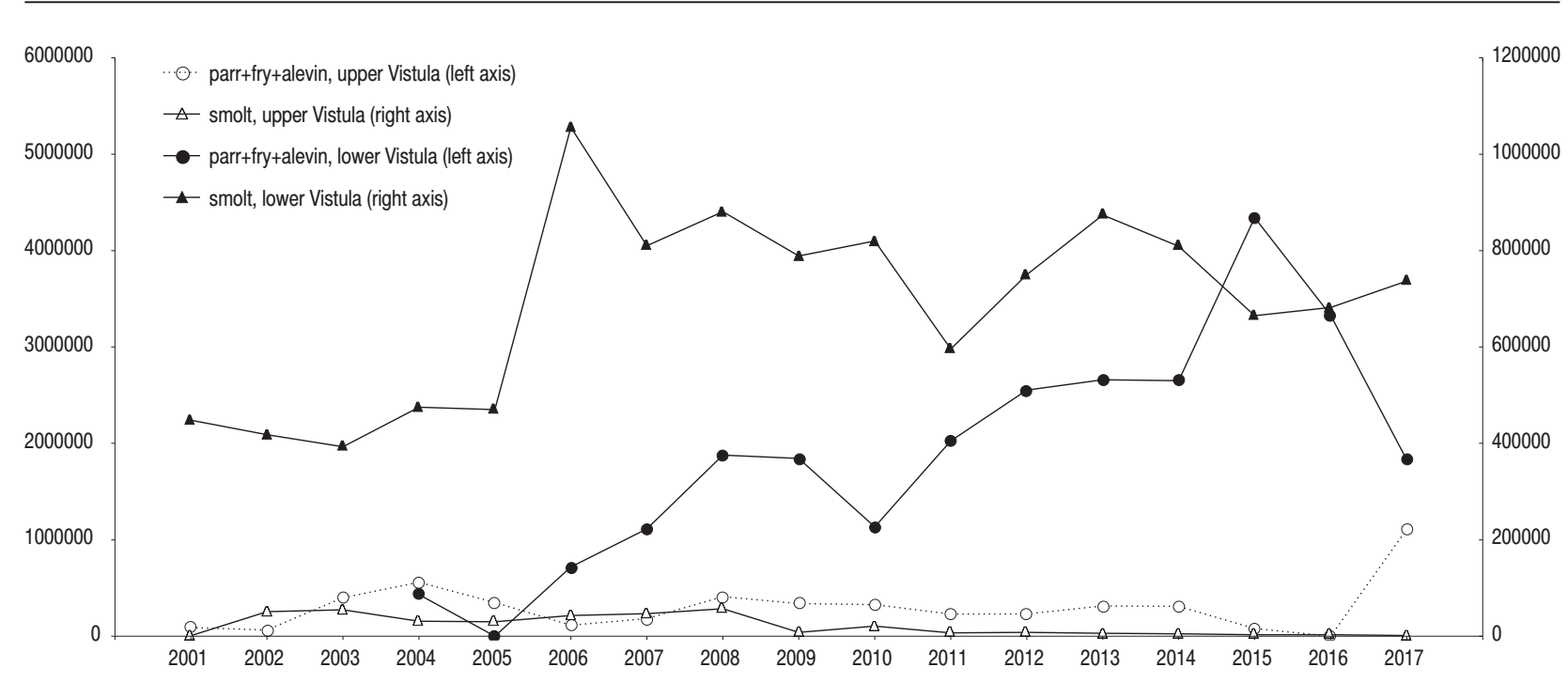

Figure 6. Stocking of the S. trutta in 2001-2017.

Vistula River. Stocking with alevins and fry was also resumed, and the numbers released rose from several hundred thousand in 2004 to more than 6.5 million in 2016. Mainly this material was released into the tributaries of the lower Vistula River (Fig. 6).

The source of the eggs for the production of this stocking material was, before 2004, almost exclusively spawners caught in the estuarine segment of the Vistula River, with just a several percent share of spawners from the Drwęca River. After 2003, along with mounting problems catching spawners, the significance of this source began to decline to an average of 39\% (from 0 to 79\%) in the 2004-2013 period. During this period, more eggs than before were obtained in the lower Drwęca at 17\% (from 7 to 33\%), while the remaining $44 \%$ (from 14 to $85 \%$ ) of eggs were obtained from cultured spawners.

Beginning in the 1980s, small quantities of the fish released originated from spawners held at the IFI hatchery in Rutki. The broodstock was cultured from eggs obtained from fish from the lower Vistula River, and until 2001 it was supplemented with these same eggs, and, in 1996 with a small quantity eggs from sea trout from the Dalälven River, which was mentioned previously and which originated from Dunajec sea trout. Thus, this broodstock comprised summer sea trout with a certain admixture of winter sea trout. At most, the fish from Rutki accounted for several percent of the fish released.

At the end of the 1990s, a certain number of immature sea trout caught in winter in the lower Vistula was delivered to the Aquamar hatchery in Miastko, and these fish were the founders of a pond stock of winter sea trout. In subsequent years, this broodstock was supplemented by single winter sea trout specimens, and in the early 2000s these fish began to deliver stocking material for release into the Vistula River. These fish comprised from 12 to $63 \%$ (average of 25\%) of the material released into the Vistula River between 2004 and 2013.

Around 2006, eggs began to be collected from another pond stock at the Dąbie fish farm that had been created with eggs obtained from fish from the lower Vistula River, which were summer fish. The significance of this source of stocking material increased in 2009, and from that time until 2013, these fish comprised from 15 to $45 \%$ (average of 30\%) of the fish released.

At the end of November 2014, the modernized fishway at the Włocławek dam was put into operation, and an automatic fish counting system was installed to monitor fish passage (Dębowski 2016). In $2015,1,566$ sea trout ascended the river through the fishway. The first period of intense migration began 
in late April and lasted until the end of June, and during this period 411 fish swam up the fishway. In summer single specimens of sea trout were noted, and by mid September the second run began that lasted until late November, during which 982 fish negotiated the pass as they migrated upstream (Dębowski 2016). In December, several sea trout swam through the fishway, and not until mid February 2016 did subsequent single specimens begin appearing. A larger run of 140 fish was noted in the second half of May, and by June only single fish were observed migrating. The fall run began in mid-October and lasted until the end of November and it numbered 450 sea trout. In 2016 a total of 811 sea trout migrated upstream through the fishway (Dębowski 2017), which was two-fold fewer than had done so in the previous year. In the subsequent year, a further decrease was noted of just 173 sea trout: 15 or so in March, 25 or so in late May and early June, and the rest from September to the first few days of November (Dębowski 2018).

\section{Genetic studies}

The first genetic study focusing on Vistula sea trout was conducted in the late 1990s and was a cytogenetic comparative analysis of Vistula sea trout and Słupia River sea trout (Woźnicki et al. 1999). The Vistula fish were cultured in Rutki. Unfortunately, we do not know if these were the progeny of pond spawners, spawners caught in the lower Vistula, or if they originated from fish from the Dalälven River. Analysis revealed the presence of two heteromorphic pairs of chromosomes, the frequency of which differed among the populations.

Łuczyński et al. (2000) studied the polymorphism of enzymatic proteins on samples of river spawners from the Vistula and the coastal Słupia, Parsęta, and Rega rivers that were collected in 1990-1994. The genetic distances among the populations studied were very small, and the most similarity was between the fish from the Vistula and Słupia rivers.
The next stage of study was the analysis of mitochondrial DNA polymorphism in sea trout. This study was performed on samples collected in 1996 from river spawners from the Vistula, Drwęca and the coastal Słupia, Wieprza, Parsęta, and Rega rivers (Włodarczyk and Wenne 2001). Sixteen composite haplotypes were identified, but only the Słupia population differed from the others.

Wąs and Wenne (2002) were the first to use microsatellite markers in studies of Vistula sea trout. Based on the polymorphism of five loci, they estimated the genetic differentiation among the progeny of Vistula sea trout cultured in ponds at Rutki from spawning in 1995, progeny of spawners caught in the lower Vistula in 1995, and spawners caught in the Vistula in 1996 and in the Rega in 1996 and 1997. No significant differences were detected between the spawners from the Vistula River and those from the Rega in 1996 or the fish from Rutki and the spawners from the Rega in 1996.

Wąs and Wenne (2003) compared spawners caught in the Vistula, Drwęca, Słupia, Wieprza, Parsęta, and Rega rivers in 1996 based on the analysis of polymorphism of seven microsatellite loci. Significant differences in the number of different alleles were found between the fish from the Vistula and Wieprza rivers, the Vistula and Parsęta rivers, and between fish from the Drwęca and those from the Wieprza and Słupia rivers.

Wąs and Bernaś (2016) used twelve microsatellite loci in a detailed genetic study of Vistula sea trout. The samples analysed came from adult sea trout caught in May 1971, downstream from the dam in Włocławek (which were winter sea trout on spawning migrations before access to the upper Vistula River was lost), sea trout caught in the lower Vistula River in winter 2010/2011 (immature, thus winter specimens), spawners from the pond stock in Miastko in 2003 (created in the 1990s with winter sea trout), and mature summer sea trout caught in fall 2003 in the Vistula estuary and in the Drwęca. Practically no differences were noted between the summer fish from the lower Vistula River and the Drwęca. All of the winter fish differed from 
one another (the fish from Miastko differed the most) and from summer fish with the exception of the similarities between the fish from the Drwęca and the winter fish from a few years later.

Drywa et al. (2013) were the first to study sea trout with single nucleotide polymorphism analysis (SNP) utilizing a microarray built for Norwegian salmon containing more than 15,000 markers. This study revealed differences among spawners from the Słupia in 2009 and smolts from the pond stock at Rutki from spawning in 2007 or 2008. SNP analysis was also used to compare Vistula sea trout (spawners from the Drwęca), sea trout from the Słupia, and seven populations from Russia, Estonia, Lithuania, and Bornholm (Poćwierz-Kotus et al. 2013). The two Polish populations differed the least from the Lithuanian population and they differed the most from the population from the eastern part of the Gulf of Finland. SNP was also used to study genetic changes in several Polish sea trout populations between 1996 and 2009 (Wenne et al. 2016). Samples from spawners caught in the Vistula, Drwęca, and four Pomeranian rivers in both years and from the stock in Miastko in 2005 were compared. The analysis indicated that in 1996 the Vistula fish (from the Vistula and Drwęca rivers) did not differ significantly from the fish from the Pomeranian rivers, but that over the course of 13 years they changed significantly and had begun to differ. The fish from the stock in Miastko differed from all of the other fish. Bernaś et al. (2018) also used SNP to analyse samples collected from fish caught in the fall in the Vistula River estuary, smolts from Rutki and Miastko, and spawners from the Słupia in 2009. The greatest genetic differences were between the fish from the two cultured stocks in Rutki and Miastko. The smolts from Miastko were most similar to the fish from the Vistula River, while the smolts from Rutki were relatively close to the fish from the Słupia. Bayesian cluster analysis confirmed that the Vistula River fish included approximately $40 \%$ of the fish from the Słupia and approximately $30 \%$ of those from Miastko. Among these was one more component that was present in quantities of approximately $30 \%$ that was also visible to a lesser degree in the fish from Miastko, which the authors concluded were originally Vistula sea trout and were linked to natural sea trout reproduction (Bernaś et al. 2018). The component from the Słupia that was present was in both cultured stocks in approximately $38 \%$ of the fish from Miastko and in $20 \%$ of those from Rutki.

A project was launched in 2014 to study the effectiveness of stocking using molecular markers (microsatellite DNA), the principles of which are presented in Wąs et al. (2017). This is based on creating a genotype base of all sea trout spawners used in artificial reproduction, and then analysing kinship and determining the origin of the fish spawning in that year that are returning to rivers. Wąs-Barcz and Bernaś (2017) reported the first results based on an examination of 1,735 Vistula sea trout spawners from the pond stocks in Miastko and Dąbie and from spawners caught in the Drwęca River in Lubicz in 2013 and a comparison of these fish to 57 fish aged $3+$ that were caught in the Vistula in 2017. Parents were identified for $20-25 \%$ of these fish (depending on the method used), half in the broodstock in Miastko and half in Dąbie. No progeny of fish from the Drwęca were found. It was assumed that the remaining fish originated from natural spawning. However, only 16 fish were not closely related, which indicated that fish participating in natural spawning could originate from previous stockings. Incidentally, it was confirmed that the effective size of pond stocks were smaller than that in the Drwęca but that all of the populations were incomparably smaller than that of the sea trout in the Rega (Wąs-Barcz and Bernaś 2017).

\section{Discussion}

Among the smolts released after 1970 none of the fish originated from winter spawners; they were the progeny of summer Vistula sea trout and of fish from coastal rivers with a similar migration period to that of the summer fish. Thus, assuming that they are distinctive and with the near total inaccessibility of the 
upper river drainage basin, the winter from of sea trout should have already been extirpated from the Vistula River in the early 1970s. Meanwhile, fish caught in the lower Vistula from November to March, which, according to Żarnecki's (1964) findings, were exclusively winter sea trout, comprised from several to over $40 \%$ of the annual catches from 1973 to 1987 (based on data from "Reports from the Salmon Management Information Service”, IFI). Two spawning runs were clearly present in sea trout migration through the fishway in Włocławek in the 2015-2017 period (Dębowski 2016, 2017, 2018). Interestingly, they fairly precisely reflect the catch distribution of sea trout catches downstream from the dam in the 1970s and 1980s (Fig. 7). Additionally, among the sea trout spawners caught in fall since the end of the 1980s in the lower Drwęca, completely immature specimens have been and continue to be noted (A. Mierzejewski, PAA Toruń - pers.comm.). Borzęcka (2003), who studied the scales of sea trout caught by recreational fishers in the Drwęca between January and June in the 1988-1992 period, concluded that $10 \%$ of these were winter fish and proposed the hypothesis that they originated from natural spawning and were the remnants of the original sea trout population from the Drwęca. According to Bontemps (1995), in the 1986-1990 period at least some sea trout migrated upstream through the two barriers equipped with simple pool fishways in the lower Drwęca. Observations of spawning in the few available tributaries indicated that their capacity was very small and the possibility of using potentially available spawning grounds in the middle course of the river, at least in the early 1990s, was problematic because of poor water quality (Szczepański 1995, Dębowski et al. 1999, Dębowski and Radtke 2000). Attempts to catch descending sea trout smolts in the middle course of the Drwęca produced 91 fish in 1992 and 21 in 1993; however, in 1992, at least, these could have included fish that had been stocked as alevins (Szczepański 1994). Bontemps (1995) estimated that several hundred fish returned to the Drwęca annually at the end of the 1980s and that this number increased with growing stocking efforts. In conclusion, the hypothesis that there was an enclave in the Drwęca basin until 1992 where sea trout spawned in numbers sufficient to maintain the original characters of winter fish thereby avoiding mixing with fish originating from stocking is unlikely.

The sudden end of the Carpathian tributaries in the upper Vistula River as sea trout rivers in the late 1960s rendered impossible further studies of the phenomenon of seasonal forms of Vistula sea trout. However, in light of history, Żarnecki's concept of

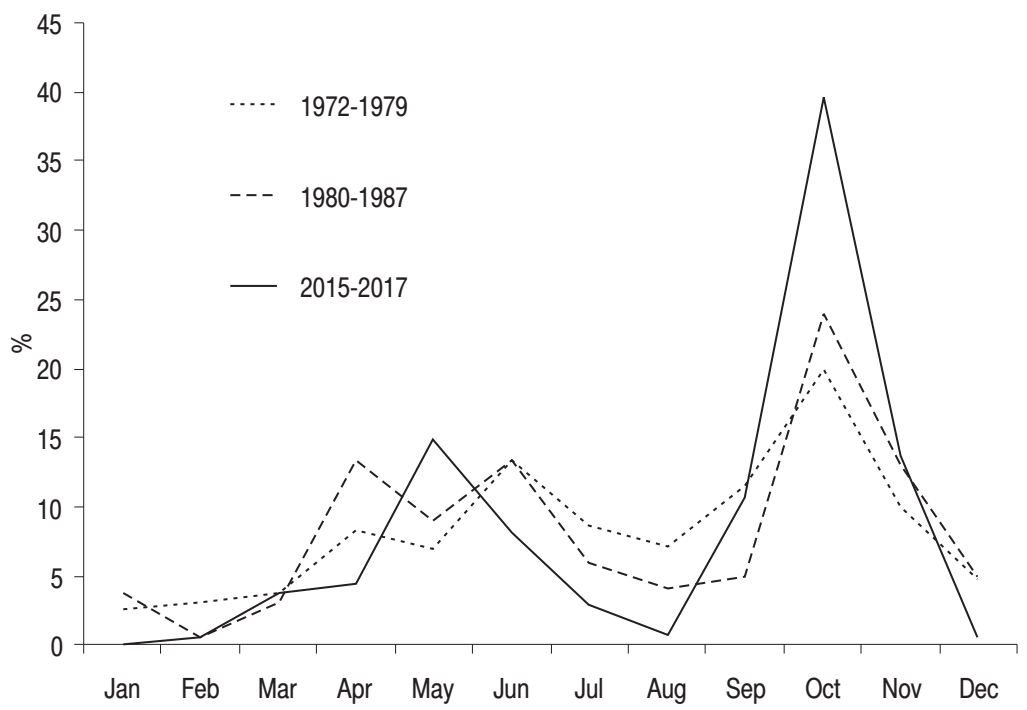

Figure 7. Distribution of commercial catches of the $S$. trutta below Włocławek dam in 1972-1979 and 1980-1987, and migration of $S$. trutta by the fishway in Włocławek in 2015-2017. 
their separateness and their association with two parts of the river basin, or ecotypes, is difficult to support. With minimal possibilities for natural reproduction and large-scale, widespread stocking (over 50 million fish released), sea trout populations have relied almost solely on these stocking efforts for more than forty years. The system for obtaining eggs for stocking purposes, with the exception of the stock in Miastko, which is marginal on the scale of the entire period, has reproduced only summer sea trout. Despite this, winter sea trout still occur today and not only in the main stream of the Vistula River, but also in the Drwęca, and they are, therefore, the progeny of summer sea trout. Contemporary winter sea trout are very different genetically from contemporary summer sea trout, as they are from the fish from Miastko, which are winter sea trout from a dozen or so years ago. This is evidence that these two seasonal forms are the result of phenotype plasticity, and not genetic polymorphism.

Eggs used to cultivate fish for stocking come from various sources and from spawning at different times. The various environmental conditions at hatcheries (mainly thermal) and the technologies used for rearing result in differences in fish growth, age, and the timing of smoltification, which, consequently, determine their futures, including mortality and maturation age. It is likely that this also determines when the fish ascend rivers and possibly even if they do so as fully immature winter fish or as nearly mature or mature summer fish. Thus, the stock of ascending fish is a mixture of fish from various stocking releases in proportions that depend on the share of fish from various sources and the effectiveness of stocking. Even if eggs are obtained from fish caught in rivers, they do not come from random spawners or even from fish representing all these groups, but only, and most frequently, from a small segment of the spawning run that is determined by catch location, timing, and the methods employed that are selected primarily to maximize catch effectiveness and logistical conditions. Therefore, the selection of fish for further reproduction is determined by migration time and size (age) that is modified by variable hydrological conditions. Historically, the share of eggs from various sources was highly variable, as is described above. The main change that has happened in the past decade or so has been the gradual shift from using spawners caught almost exclusively in the Vistula River to using mainly spawners from pond stocks. The results of this are already apparent: in 2003 the fish from the Vistula River and Miastko were very distant genetically (Wąs and Bernaś 2016), but after a few years of stocking with fish from this hatchery, by 2009 these fish had become significantly closer genetically (Bernaś et al. 2018). This is a very serious change. The broodstock has not been refreshed for veterinary reasons for many years, and subsequent generations originating from them are the progeny of one or several groups of founders. They were subjected to very strong selection that differed from both natural selection and the selection that resulted from harvesting eggs from fish caught in rivers, which distanced them genetically from contemporary river fish and from founder fish. Propagating a set of traits that results in fish appearing at a certain time and location and in a specific stage of sexual maturity and another set that includes other features for increasing rearing success effectively prevents Vistula sea trout from being able to adapt in any way to changing environmental conditions.

We do not know the size of the historical sea trout population in the Vistula River. The largest catches in the lower Vistula were approximately 110 tons in the first years following World War II (Jokiel 1953b) and 129 tons in 1991 (Bartel 1993), which are amounts that more or less correspond to 30,000 to 40,000 fish. In the first period, these fish originated mainly from natural spawning in the upper part of the drainage basin, while in the second, nearly all of them originated from stocking. These catch statistics did not include Vistula sea trout caught in the sea, and the reporting systems were incomplete as they did not include illegal catches. Certainly, not all sea trout were caught. It appears that a safe estimate of the record number of sea trout ascending the Vistula River in these years was from 50,000 to 60,000 . In the other years, after the Vistula River was dammed at Włocławek, the 
number of fish was likely much smaller, and, if the proportions above are maintained, it was usually approximately 20,000 to 30,000 . The total collapse of sea trout fishery in the lower Vistula River in recent years is explained by competition from seals (ICES 2018). If sea trout are not caught in the lower river (although there are serious and justified concerns regarding the reliability of fishing statistics from recent years) and they are not consumed by seals (which seems unlikely, at least on such a mass scale), they should appear in the fishway in Włocławek in substantially larger numbers than 800 to 1,600 fish. This was more or less the number of fish caught downstream from Włocławek in the 1970s and 1980s, but this number was also from several to fifteen or so percent of the total sea trout catches at the time in the lower Vistula. Meanwhile, according to lease-holders exploiting these waters, only 143 sea trout were caught in the Vistula in 2017, and 173 navigated the fishway in Włocławek, and practically none were observed downstream from the barrier in Lubicz on the Drwęca. Some number of fish certainly ascended to spawn in the tributaries downstream from Włocławek, including the lower Wierzyca, Zielona Struga, and Mień, but the area and potential of these spawning grounds is very small especially if no sea trout were observed migrating up the Drwęca through Lubicz, and nothing is known regarding the specific densities of fish in these spawning grounds in the fall of 2017. Thus, even assuming that unreported catches exceeded those reported, it is difficult to estimate the number of fish that ascended the Vistula River in 2017 at more than 1,000. They were probably not caught at sea earlier, because Polish marine catches of sea trout in the early twenty-first century were 700-800 tons, after which they decreased to 148 and 152 tons in 2016 and 2017, respectively (ICES 2018), and they included not only Vistula but also Pomeranian sea trout. Additionally, they were also overestimated because of erroneous reporting of salmon as sea trout (ICES 2018). The majority of fish ascending the Vistula River in 2017 were fish from spawning in 2013. The study by Wąs-Barcz and Bernaś (2017) indicated that the share of reared fish among them was about 20\%, which means that of the 1,000 fish, 200 were from stocking. Meanwhile, the magnitude of stocking with fish from spawning in 2013 in various developmental stages (alevins, fry, smolts) was over 3.5 million individuals! Is it possible that the 800 other fish came from spawning in remnant spawning grounds? It would appear that with sufficient survival rates, the answer is yes, especially since there were more fish in the Vistula at the time, which is evidenced by commercial catches in the lower course of the river and by the fact that substantially more fish ascended the Drwęca where there are the most potential spawning grounds, which, in turn, is evidenced by catches of spawners downstream from the barrier in Lubicz. Obviously, it bears remembering that most of the fish spawning naturally also originated from stocking.

Even though we have observed a rapid decline in the number of fish in the river over the past three years, it is difficult to speak of a population collapse, because even if no fish return to ascend the river to spawn, stocking can be continued using material obtained from cultured stocks. From the point of view of population restoration, this is senseless. The current Vistula sea trout population has already moved away from the historical population significantly, and this process has accelerated recently. The population is losing or has already lost its biological potential and its ability to adapt, which is evidenced by the minimal number of fish migrating upstream in the river basin toward historical spawning grounds. Of course, with such huge stocking releases, single fish will survive to spawn and will do so in the remnant spawning grounds, but this certainly does not attest to any self-sustaining population. Stocking remains an important form of support for commercial fisheries, above all for marine fisheries. Studies of stocking the Vistula River with smolts from the 1960s to the 1980s (Bartel and Dębowski 1996, Dębowski and Bartel 1996) indicated that they were highly effective. It seems that with regard to this question, too, there has been a huge change. Despite much larger quantities of youbg being released in the 1990s and the continuation of this to the present, sea trout catches 
have not only declined in the Vistula River, but also in the sea, and this trend will continue.

\section{References}

Backiel T. 1985 - Fall of migratory fish populations and changes in commercial fisheries in impounded rivers in Poland Habitat Modification and Freshwater Fisheries: 28-41.

Bartel R. 1988 - Trouts in Poland - Pol. Arch. Hydrobiol. 35: 321-339.

Bartel R. 1993 - Present situation of the Vistula sea trout Arch. Pol. Fish. 1: 101-203.

Bartel R. 2002 - Diadromous fish, their commercial importance, and restoration programs for these species Suppl. Acta Hydrobiol. 3: 37-55 (in Polish).

Bartel R. 2006 - Can we save Vistula River sea trout? Komun. Ryb. 3: 17-19 (in Polish).

Bartel R., Bontemps S. 1989 - Downstream migration of brown trout (Salmo trutta L.) smolts over the dam at Włocławek on the Vistula River - Rocz. Nauk. PZW 2: 7-14 (in Polish).

Bartel R., Dębowski P. 1996 - Stocking of sea trout (Salmo trutta m. trutta) smolts in Poland. Part I. Preliminary analysis of tagging experiments - Arch. Pol. Fish. 4: 5-18.

Bartel R., Pachur M., Bernaś R. 2010 - Distribution, migrations, and growth of tagged sea trout released into the Vistula River - Arch. Pol. Fish. 18: 225-237.

Bartel R., Wiśniewolski W., Prus P. 2007 - Impact of the Wloclawek dam on migratory fish in the Vistula River Arch. Pol. Fish. 15: 141-156.

Beacham T.D., Cox-Rogers S., MacConnachie C., McIntosh B., Wallace C.G. 2014 - Population structure and run timing of Sockeye Salmon in the Skeena River, British Columbia - N. Am. J. Fish. Manage. 34: 335-348.

Beacham T.D., Wallace C.G., Le K.D., Beere M. 2012 - Population structure and run timing of steelhead in the Skeena River, British Columbia - N. Am. J. Fish. Manage. 32: 262-275.

Berg L.S. 1934 - Yarovye i ozimye rasy u prokhodnych ryb Izviestiia Akademii Nauk SSSR, Otdel Matematicheskikh i Estestvennykh Nauk 5: 700-732.

Bernaś R., Arnyasi M., Kent M.P., Lien S., Wenne R. 2018 Hatchery origin and selection evidence in the sea trout populations from southern Baltic Sea - Ecol. Evol. in press.

Biegała L. 1972 - Fishway at the barrage in Włocławek Gosp. Wodna 5: 192-194 (in Polish).

Bieniarz K., Epler P. 1977 - Fish passage through hydroelectric turbines in Poland - Gosp. Ryb. 29: 12-13 (in Polish).

Bontemps S. 1977 - Fish migration through the fishway at the damn on the Vistula River - Gosp. Ryb. 29: 18-19 (in Polish).
Bontemps S. 1995 - Migrations of sea trout to Drwęca - Rocz. Nauk. PZW 8: 53-74 (in Polish).

Borzęcka I. 1998 - The historical picture of summer and winter sea trout occurrence in the Vistula River - Bull. Sea Fisheries Institute 145: 51-56.

Borzęcka I. 1999 - The age of migrating Vistula sea trout and the variability of smolt recruitment to the sea before damming the river - Bull. Sea Fisheries Institute 148: 3-21.

Borzęcka I. 2001 - Growth of Vistula sea trout (Salmo trutta m.trutta L.) based on adults caught in the Vistula River prior to the construction of the dam in Wloclawek - Bull. Sea Fisheries Institute 2: 3-12.

Borzęcka I. 2003 - Characteristics of sea trout (Salmo trutta m. trutta) from the Drweca River based on scale samples collected between 1988-1992 - Arch. Pol. Fish. 11: 165-179.

Chrzanowski F. 1969 - What is next for salmonid management in the Vistula River? - Gosp. Ryb. 21: 3-4 (in Polish).

Chrzanowski F. 1971 - Salmonid management in the lower Vistula River requires a shift in its guiding principles Gosp. Ryb. 23: 3-5 (in Polish).

Cios S. 2003 - Comments on the occurrence of trout, salmon, and grayling in Polish waters in the past - Rocz. Nauk. PZW 16: 17-31 (in Polish).

Cucherousset J., Ombredane D., Charles K., Marchand F., Bagliniere J.L. 2005 - A continuum of life history tactics in a brown trout (Salmo trutta) population - Can. J. Fish. Aquat. Sci. 62: 1600-1610.

Dahl J., Dannewitz J., Karlsson L., Petersson E., Loef A., Ragnarsson B. 2004 - The timing of spawning migration: implications of environmental variation, life history, and sex - Can. J. Zool. 82: 1864-1870.

Dębowski P. 2002 - Smoltification and maturity of sea trout, Salmo trutta m. trutta L., in a hatchery - Arch. Pol. Fish.10, Suppl. 1: 5-72 (in Polish).

Dębowski P. 2016 - Fish passage through the Włocławek dam fishway in 2015 - Komun. Ryb. 153: 1-7 (in Polish).

Dębowski P. 2017 - Fish passage through the Włocławek dam fishway in 2016 - Komun. Ryb. 157: 1-6 (in Polish).

Dębowski P. 2018 - Fish passage through the Włocławek dam fishway in 2017 and preliminary analysis of fish runs in 2015-17 - Komun. Ryb. 2: 7-12 (in Polish).

Dębowski P., Bartel R. 1995 - Homing of tagged sea trout (Salmo trutta L.) smolts released into Polish rivers Arch. Pol. Fish. 3: 107-122.

Dębowski P., Bartel R. 1996 - Stocking of sea trout (Salmo trutta m. trutta) smolts in Poland. Part II. Factors influencing recaptures and verification of estimates - Arch. Pol. Fish. 4: 19-36.

Dębowski P., Radtke G. 2000 - Seat trout, Salmo trutta morpha trutta L., spawning sties in the Drwęca River 
basin - XVIII Zjazd Hydrobiologów Polskich w Białymstoku, 2-4 września 2000 (in Polish).

Dębowski P., Radtke G., Szczepański Z. 1999 - Sea trout (Salmo trutta m. trutta L.) in the Brynica River (Drwęca River drainage basin) - Rocz. Nauk. PZW 12: 104-112 (in Polish).

Dixon B. 1924a - Morphometrical features of the sea-trout of Polish rivers - J. Cons. Int. Explor. Mer.: 94-102.

Dixon B. 1924b - First salmon campaign on the Dunajec River (Część II) - Rybak Polski 5: 150-166 (in Polish).

Dixon B. 1924c - Age and growth rate of the sea-trout Salmo trutta of the rivers Reda and Dunajec - J. Cons. Int. Explor. Mer 6: 449-457.

Drywa A., Poćwierz-Kotus A., Wąs A., Dobosz S., Kent M.P., Lien S., Bernaś R., Wenne R. 2013 - Genotyping of two populations of Southern Baltic Sea trout Salmo trutta m. trutta using an Atlantic salmon derived SNP-array Marine Genomics 9: 25-32.

Eiler J.H., Evans A.N., Shreck C.B. 2015 - Migratory patterns of wild Chinook salmon Oncorhynchus tshawytscha returning to a large, free-flowing river basin - PLoS ONE 10: e0123127.

Elliott J.M. 1989 - Wild brown trout Salmo trutta: an important national and international resource - Freshwater Biol. 21: 1-5.

Elliott,J.M. 1994 - Quantitative ecology and the brown trout Oxford University Press, New York, 286 p.

Ferguson A. 1989 - Genetic differences among brown trout, Salmo trutta, stocks and their importance for the conservation and management of the species - Freshwater Biol. 21: 35-46.

Ferguson A. 2006 - Genetics of sea trout, with particular reference to Britain and Ireland - In: Sea trout: biology, conservation, and management (Eds) G. Harris, N. Milner. Proceeding of the First International Sea Trout Symposium, July 2004, Cardiff, Wales, UK. Blackwell Publishing, Oxford: 155-182.

Fleming I.A. 1996 - Reproductive strategies of Atlantic salmon: Ecology and evolution - Rev. Fish Biol. Fish. 6: 379-416.

Gurney W.S.C., Bacon P.J., Speirs D.C., McGinnity P., Verspoor E. 2012 - Sea-age variation in maiden Atlantic salmon spawners: phenotypic plasticity or genetic polymorphism? - B. Math. Biol. 74: 615-640.

Guyomard R. 1999 - Genetic diversity and the management of natural populations of brown trout - In: Biology and ecology of the brown trout and sea trout (Eds) J.L. Bagliniere., G. Maisse, Springer-Praxis Series in Aquaculture and Fisheries: 205-227.

Hansen L.P., Jonsson B. 1991 - Evidence of a genetic component in the seasonal return pattern of Atlantic salmon, Salmo salar L. - J. Fish Biol. 38: 251-258.

HELCOM 2011 - Salmon and Sea Trout Populations and Rivers in Poland - HELCOM assessment of salmon
(Salmo salar) and sea trout (Salmo trutta) populations and habitats in rivers flowing to the Baltic Sea - Balt. Sea Environ. Proc. No. 126B: 1-59.

ICES 2018 - Report of the Baltic Salmon and Trout Assessment Working Group (WGBAST), 20 -28 March 2018, Turku, Finland - ICES CM 2018\ACOM: xx: 1-xxx.

Jamshidi S., Kalbassi M.R. 2011 - Conspecific relation between two seasonal migratory forms of endangered Caspian trout, Salmo trutta caspius Kessler, 1877, revealed by RAPD markers - Iran J. Fish Sci. 10: 437-446.

Jokiel J. 1953a - First attempt to obtain fertilized eggs from the sea tout summer spawning run in the lover Vistula River - Gosp. Ryb. 5: 9-11 (in Polish).

Jokiel J. 1953b - Sea trout catches in the Gdańsk Voivodeship in 1952 - Gosp. Ryb. 5: 3-5 (in Polish).

Jokiel J. 1961 - Results of tagging Vistula River sea trout smolts - Gosp. Ryb. 13: 18-20 (in Polish).

Jonsson B. 1985 - Life history patterns of freshwater resident and sea-run migrant brown trout in Norway - Trans. Am. Fish. Soc. 114: 182-194.

Juszczyk W. 1951 - Fish passage through the turbines of the Rożnów Dam - Rocz. Nauk Rol. 57: 307-335 (in Polish).

Klemetsen A., Amundsen P.A., Dempson J.B., Jonsson B., Jonsson N., O’Connell M.F., Mortensen E. 2003 - Atlantic salmon Salmo salar L. brown trout Salmo trutta L. and Artic charr Salvelinus alpinus (L.): a review of aspects of their life histories - Ecol. Freshw. Fish 12: 1-59.

Kołder W. 1946 - About the salmon campaign in the Dunajec River - Prz. Ryb. 13: 86-88 (in Polish).

Kołder W. 1954 - The salmon campaign in the upper Vistula River basin in 1953 - Gosp. Ryb. 6: 5-8 (in Polish).

Kołder W. 1955 - Obtaining salmon and sea trout eggs in the upper Vistula River basin 1954 - Gosp. Ryb. 7: 5-7 (in Polish).

Kołder W. 1957 - The salmon campaign in the upper Vistula River basin in 1956 - Gosp. Ryb. 9: 6-7 (in Polish).

Kołder W. 1958 - Stocking of the upper Vistula River system with salmon and sea trout from 1879 to 1954 - Rocz. Nauk Rol. 73-B-2: 215-267 (in Polish).

Kołder W. 1961 - Current state of fisheries in the upper Vistula River basin - Gosp. Ryb. 13: 11-13 (in Polish).

Kossakowski Z. 1959 - Sea trout campaign in the lower Vistula River in 1958 - Gosp. Ryb. 11: 5-6 (in Polish).

Kossakowski Z. 1969 - Spawning base in Świbno - Gosp. Ryb. 21: 3-5 (in Polish).

Kukucz Z. 1960 - Alterations in fat, water and protein content of Vistula sea trout in connection with their biology ICES C.M. 1960/129.

Kukucz Z. 1961 - Some of the differences between summer and winter populations of sea-trout (Salmo trutta L.) ICES C.M. 1961/77.

Kulmatycki W. 1932 - On studies of migratory sea trout in Poland - Czasopismo Przyrodnicze I-II: 3-10 (in Polish). 
Larsen P.F., Nielsen E.E., Koed A., Thomsen D.S., Olsvik P.A., Loeschcke V. 2008 - Interpopulation differences in expression of candidate genes for salinity tolerance in winter migrating anadromous brown trout (Salmo trutta L.) - BMC Genetics 9: 1-9.

Lilja J., Romakkaniemi A. 2003 - Early-season river entry of adult Atlantic salmon: its dependency on environmental factors - J. Fish Biol. 62: 41-50.

Linnik V., Malinin L.K., Woźniewski M., Sych R., Dębowski P. 1998 - Movements of adult sea trout Salmo trutta L. in the tailrace of a low-head dam at Wloclawek hydroelectric station on the Vistula River, Poland - Hydrobiologia 371/372: 335-337.

Lubecki F., Dixon B. 1925 - Report on the second salmon campaign in 1924 - Arch. Pol. Fish. 1: 384-405 (in Polish).

Łuczyński M., Bartel R., Vuorinen J.A., Domagała J., Żółkiewicz L., Brzuzan P. 2000 - Biochemical genetic characteristics of four Polish sea trout (Salmo trutta trutta L.) populations - Pol. Arch. Hydrobiol. 47: 21-28.

Łysak A., Bieniarz K. 1975 - Impact of humans on the aquatic environment and ichthyofauna in southern Poland Gosp. Ryb. 27: 6-9 (in Polish).

Morawska B. 1967 - Fecundity of sea trout (Salmo trutta L.) from the Vistula River - Rocz. Nauk Rol. 90-H-2 (in Polish).

Poczopko P., Słonowski A. 1958 - A contribution to the fishery-biological characteristics of the lower Vistula River Zesz. Nauk. WMK w Toruniu, Nauki Mat-Przyr., Biol., Zesz. 3: 3-36 (in Polish).

Poćwierz-Kotus A., Bernaś R., Dębowski P., Kent M.P., Lien S., Kesler M., Titov S., Leliuna E., Jespersen H., Drywa A., Wenne R. 2013 - Genetic differentiation of southeast Baltic populations of sea trout inferred from single nucleotide polymorphisms - Anim. Genet. 45: 95-104.

Quinn T.P., McGinnity P., Reed T.E. 2016 - The paradox of "premature migration" by adult anadromous salmonid fishes: patterns and hypotheses - Can. J. Fish. Aquat. Sci. 73: 1015-1030.

Schechtel E. 1925 - Salmon (Salmo salar L.) and sea trout (Salmo trutta L.) - Roczniki Nauk Rolniczych i Leśnych 14: 283-346 (in Polish).

Schoennet R., Gęsicki Z. 1958 - Catching, transporting, and keeping salmon and sea trout spawners from the lower Vistula in light of observations from previous experiences - Roczn. Nauk Rol. 73-B-2 (in Polish).

Schtickzelle N., Quinn T.P. 2007 - A metapopulation perspective for salmon and other anadromous fish - Fish Fish. 8: 297-314.

Skrochowska S. 1969 - Migrations of the sea-trout (Salmo trutta L.), brown-trout (Salmo trutta m. fario L.) and their crosses. Part IV. General discussion of results - Pol. Arch. Hydrobiol. 16: 181-192.
Stewart D.C., Smith G.W., Youngson A.F. 2002 - Tributary-specific variation in timing of return of adult Atlantic salmon (Salmo salar) to fresh water has a genetic component - Can. J. Fish. Aquat. Sci. 59: 276-281.

Strange J.S. 2012 - Migration strategies of adult Chinook salmon runs in response to diverse environmental conditions in the Klamath River basin - Trans. Am. Fish. Soc. 141: 1622-1636.

Summers D.W. 1996 - Differences in the time of river entry of Atlantic salmon, Salmo salar L., spawning in different parts of the River North Esk - Fisheries Manag. Ecol. 3: 209-218.

Sych R. 1998 - Migratory fish restoration programs in Poland - from their genesis to initial implementation - Idee Ekol., Ser. Szkice 13: 71-86 (in Polish).

Szczepański Z. 1994 - Assessing the effectiveness of migratory sea trout natural spawning in the Drwęca River basin. Using streams in the Drwęca basin for rearing smolts - Komun. Ryb. 4: 21-25 (in Polish).

Szczepański Z. 1995 - Studies on the effectiveness of migratory sea trout natural spawning in the Drwęca River basin and the effects of stocking sea trout alevins into the Brynica River system - Komun. Ryb. 6: 28-31 (in Polish).

Szupryczyński J. 1986 - Influence of the Włocławek reservoir on the geographical environment (summary) - In: The Włocławek Reservoir - Some problems of physical geography (Ed.) J. Szupryczyński, Dokumentacja Geograficzna, Instytut Geografii i Przestrzennego Zagospodarowania PAN: 7-24 (in Polish).

Vaha J.P., Erkinaro J., Niemela E., Primmer C.R., Saloniemi I., Johansen M., Svenning M., Brors S. 2011 - Temporally stable population-specific differences in run timing of one-sea-winter Atlantic salmon returning to a large river system - Evolutionary Applications 4: 39-53.

Wąs A., Bernaś R. 2016 - Long-term and seasonal genetic differentiation in wild and enhanced stocks of sea trout (Salmo trutta m. trutta L.) from the Vistula River, in the southern Baltic - management implications - Fish. Res. 175: 57-65.

Wąs A., Wenne R. 2002 - Genetic differentiation in hatchery and wild sea trout (Salmo trutta) in the Southern Baltic at microsatellite loci - Aquaculture 204: 493-506.

Wąs A., Wenne R. 2003 - Microsatellite DNA polymorphism in intensely enhanced populations of sea trout (Salmo trutta) in the Southern Baltic - Mar. Biotechnol. 5: 234-243.

Wąs A., Bernaś R., Wenne R. 2017 - The genetic approach for assessing sea trout stock enhancement efficiency - An example from the Vistula River - Arch. Pol. Fish. 25: 65-75.

Wenne R., Bernaś R., Poćwierz-Kotus A., Drywa A., Wąs A. 2016 - Recent genetic changes in enhanced populations of sea trout (Salmo trutta m. trutta) in the southern Baltic 
rivers revealed with SNP analysis - Aquat. Living Resour. 29: 103.

Wenne R., Łuczyński M., Bartel R. 2000 - Assessing the possibilities of differentiating migratory sea trout populations in Poland using genetic methods - Stud. Mat. MIR Ser. B 71: 11-19.

Wiśniewolski W. 1987 - Commercial fish catches in the Vistula, Oder, and Warta rivers from 1953 to 1978 Rocz. Nauk Rol. Ser. H-101: 71-114 (in Polish).

WiśniewolskiW., Augustyn L., Bartel R., Depowski R., Dębowski P., Klich M., Kolman R., Witkowski A. 2004 Polish river continuity and restoring migratory fish WWF Polska, Warszawa, 42 p (in Polish).

Woźnicki P., Jankun M., Kucharczyk D., Boroń A., Łuczyński M. 1999 - Cytogenetic characterization of sea trout (Salmo trutta) from Poland - Copeia 2: 501-505.

Woźniewski M., Dębowski P., Bartel R. 1999 - Telemetric observations of the behaviour of Vistula sea trout (Salmo trutta morpha trutta L.) below the dam of Włocławek Reservoir in an attempt to improve fish passage - Rocz. Nauk. PZW 12: 5-18 (in Polish).

Włodarczyk E., Wenne R. 2001 - Mitochondrial DNA variation in sea trout from coastal rivers in the southern Baltic region - ICES J. Mar. Sci. 58: 230-237.

Żarnecki S. 1952a - Summer salmon and sea trout in the Vistula River basin - Gosp. Ryb. 4: 3-5 (in Polish).
Żarnecki S. 1952b - Seasonal races of salmonids - Gosp. Ryb. 4: 2-4 (in Polish).

Żarnecki S. 1956 - Summer and winter races of salmon and sea trout from the Vistula River -ICES C.M.

Żarnecki S. 1957 - The age and growth of seasonal populations of sea trout entering the river Vistula in autumn 1951 - ICES C.M. 1957/73..

Żarnecki S. 1960a - General conclusions on scale readings of salmon, sea trout, and brown trout originating in the Vistula - ICES C.M. 1960/128.

Żarnecki S. 1960b - Recent changes in the spawning habits of sea trout in the upper Vistula -ICES J. Mar. Sci. 25: 326-331.

Żarnecki S. 1963 - Occurrence of seasonal populations of Atlantic salmon (Salmo salar L.) and sea trout (Salmo trutta L.) in the Vistula River - Acta Hydrobiol. 5: 255-294 (in Polish).

Żarnecki S. 1964 - Timing of summer and winter populations of sea trout and Atlantic salmon ascending the Vistula River in the 1952 annual cycle - Acta Hydrobiol. 6: 255-267 (in Polish).

Żarnecki S., Kołder W. 1955 - Observations of fish passing through the fishways at Rożnów and Czchów - Roczn. Nauk Rol. 69-B: 501-525 (in Polish).

Żarnecki S., Piątek M. 1954 - Metabolic differences in winter and summer salmon and sea trout - Folia Biol. 2: 3-4 (in Polish). 